\title{
THE COMPOSITION OF VOLATILE SUBSTANCES OF COWBERRY LEAVES
}

\author{
M.A.Komisarenko \\ National University of Pharmacy \\ Key words: cowberry; leaves; volatile substances; gas chromatography
}

\begin{abstract}
The qualitative composition and quantitative content of volatile substances of cowberry leaves (Vaccinium vitis-idaea L.) has been studied by gas chromatography. Identification of substances has been performed based on comparison of the mass spectra obtained with the data of the NIST05WILEY library (approximately 500000 mass spectra). The retention indices of the components have been calculated according to the results of control tests of substances with addition of the mixture of normal alkanes $\left(C_{10}-C_{18}\right)$. In cowberry leaves 51 substances have been found, 50 of them have been identified; squalene, palmitic acid, ethyl palmitate, oleic acid prevail. It has been determined that the content of volatile substances is $0.025 \%$. Monoterpenes are presented by 14 substances, derivatives of linalool, geraniol, thymol and eugenol are prevalent. Caryophyllene oxide and farnesyl acetone $C$ prevail among sesquiterpenes. Among organic and fatty acids the predominant substances are lauric, myristic, pentadecanoic, palmitoleic, palmitic, linoleic and linolenoic acids.
\end{abstract}

In the world there is a tendency of growing interest in phytotherapy. Microorganisms have developed resis tance to many existing antibacterial agents; therefore, the use of the medicinal plant raw material for creating antimicrobial drugs is an urgent direction of development of pharmaceutical science. The promising plant to create a new herbal medicine is cowberry (Vaccinium vitis-idaea L.), its resources are sufficient in Ukraine.

In traditional and official medicine a decoction of cowberry leaves is used as a highly effective medicine for the treatment of diseases of the kidney and the urinary tract. However, this dosage form has a number of disadvantages: difficulty to prepare, the absence of standardization, impossibility of long-term storage, continuous use of the medicinal plant raw material. Thus, creation of a new standardized medicine based on biologically active substances of cowberry leaves is topical [5].

It is commonly known that phenolic compounds are the main group of substances with the pharmacological action of this medicinal plant raw material. Previously, we reported on the qualitative and quantitative chemical determination of some BAS classes in leaves and extracts of cowberry. They are: simple phenols, derivatives of hydroxycinnamic acid, flavonoids, polyphenolic compounds and organic acids $[1,2,3]$. Continuing the studies of BAS of cowberry leaves and products of their processing our attention was drawn to the fact that the composition of the volatile substances has not been studied yet. The raw material has a specific odour; therefore, the aim of our work was to study the chemical composition of the volatile fraction of cowberry leaves since their qualitative and quantitative composition may affect the overall pharmacological effect of the drug created on its basis.

\section{Materials and Methods}

The object of research was cowberry leaves bought in the chemist's shop (batch 0715, manufactured by "Phyto svit" firm).

To obtain the essential oil from the raw material studied the method allowing to isolate the essential oil from a small amount of the plant raw material was used [6]. For distillation $22 \mathrm{ml}$ "Agilent" vials (part number 5183-4536) with open lids and silicone seal were used. The weighed quantity of 2.0-3.0 g of the plant material was placed in a vial and filled with water to half the volume. The vial was closed with a lid with an air refrigerator and boiled on a sand bath for an hour. To avoid losses the trace amounts of the essential oil adsorbed on the inner surface of the refrigerator were washed twice with 1-2 $\mathrm{ml}$ of petroleum ether; the washings were collected to the vial.

The qualitative composition and quantitative content of terpenoids were determined by gas chromatography using an Agilent Technology 6890 gas chromatograph (GC) with a mass spectrometric detector 5973 (MS). For analysis the HP-5 chromatographic column with the length of $30 \mathrm{~m}$ and the internal diameter of $0.25 \mathrm{~mm}$ was used. The analysis was carried out under the following conditions: the thermostat temperature was programmed from $50^{\circ} \mathrm{C}$ to $250^{\circ} \mathrm{C}$ at the rate of $4^{\circ} \mathrm{C} / \mathrm{min}$; the temperature of the sample injection heater was $250^{\circ} \mathrm{C}$; the carrier gas was helium; the flow rate $-\mathrm{ml} / \mathrm{min}$; the flow from $\mathrm{GC}$ to $\mathrm{MS}$ was heated to $230^{\circ} \mathrm{C}$; the source temperature was maintained at $200^{\circ} \mathrm{C}$; electron ionization was carried out at $70 \mathrm{eV}$ in the mass ranging from $\mathrm{m} / \mathrm{z} 29$ to 450 . Identification was performed based on comparison of the mass spectra obtained with the data of the NIST05-WILEY library (approximately 500000 
Table

Continuation of Table

The chemical composition of volatile substances of cowberry leaves

\begin{tabular}{|c|c|c|c|}
\hline No. & $\begin{array}{l}\text { Retention } \\
\text { time }\end{array}$ & The substance identified & $\begin{array}{c}\text { The content } \\
\text { of volatile } \\
\text { substances } \\
(\mathrm{mg} / \mathrm{kg})\end{array}$ \\
\hline 1 & 2 & 3 & 4 \\
\hline 1 & 8.886 & trans-linalool oxide & 0.74 \\
\hline 2 & 9.333 & cis-linalool oxide & 0.49 \\
\hline 3 & 9.803 & linalool & 5.03 \\
\hline 4 & 12.124 & terpinene-4-ol & 0.78 \\
\hline 5 & 12.217 & p-cumene-8-ol & 0.30 \\
\hline 6 & 12.556 & p-ment-1-en-8-ol & 14.05 \\
\hline 7 & 15.301 & geraniol & 2.03 \\
\hline 8 & 16.033 & thymol & 3.64 \\
\hline 9 & 17.637 & eugenol & 2.84 \\
\hline 10 & 19.002 & caprylic acid & 1.55 \\
\hline 11 & 19.241 & \begin{tabular}{|l|}
$1,2,3,4-t e t r a h y d r o-2,5,8-$ \\
trimethylnaphthalene- \\
1-ol
\end{tabular} & 0.35 \\
\hline 12 & 19.557 & oct-7-en-2-ol & 0.26 \\
\hline 13 & 19.942 & tetradecane & 0.59 \\
\hline 14 & 20.451 & $*$ & 0.46 \\
\hline 15 & 20.79 & geranyl acetone & 5.10 \\
\hline 16 & 21.577 & trans- $\beta$-ionone & 0.64 \\
\hline 17 & 21.662 & cis- $\beta$-ionone & 1.11 \\
\hline 18 & 22.541 & a-muurolene & 0.87 \\
\hline 19 & 22.826 & $\gamma$-cadinene & 0.92 \\
\hline 20 & 23.042 & a-bisabolol & 0.83 \\
\hline 21 & 24.514 & caryophyllene oxide & 4.15 \\
\hline 22 & 24.807 & lauric acid & 2.03 \\
\hline 23 & 25.185 & benzophenone & 3.06 \\
\hline
\end{tabular}

\begin{tabular}{|c|c|l|c|}
\hline 1 & 2 & \multicolumn{1}{|c|}{3} & 4 \\
\hline 24 & 26.218 & tau-muorol & 1.65 \\
\hline 25 & 26.519 & a-cadinol & 1.26 \\
\hline 26 & 27.136 & vinyl laurinate & 0.37 \\
\hline 27 & 27.622 & $\begin{array}{l}6,10 \text {-methylundecane- } \\
\text { 2-one }\end{array}$ & 0.22 \\
\hline 28 & 29.194 & myristic acid & 9.11 \\
\hline 29 & 29.472 & ethyl myristate & 1.39 \\
\hline 30 & 30.297 & $6,10,14-$ pentadec-2-one & 4.24 \\
\hline 31 & 30.736 & pentadecanoic acid & 5.47 \\
\hline 32 & 31.222 & farnesyl acetone C & 3.03 \\
\hline 33 & 31.901 & palmitoleic acid & 19.14 \\
\hline 34 & 32.34 & palmitic acid & 49.39 \\
\hline 35 & 32.464 & ethyl palmitate & 11.02 \\
\hline 36 & 32.626 & $14-\beta$-pregnane & 2.36 \\
\hline 37 & 34.144 & linoleic acid & 4.29 \\
\hline 38 & 34.299 & linolenoic acid & 5.99 \\
\hline 39 & 34.345 & oleic acid & 10.14 \\
\hline 40 & 34.43 & ethyl linoleate & 0.98 \\
\hline 41 & 34.476 & ethyl linolenoate & 0.52 \\
\hline 42 & 34.538 & ethyl oleinoate of stearic & 1.05 \\
\hline 43 & 34.615 & ethyl stearate & 4.32 \\
\hline 44 & 34.885 & tricosane & 0.48 \\
\hline 45 & 36.226 & tetracosane & 0.91 \\
\hline 46 & 36.789 & pentacosane & 0.25 \\
\hline 47 & 37.259 & hexacosane & 0.69 \\
\hline 48 & 38.269 & heptacosane & 4.10 \\
\hline 49 & 40.128 & squalene & 2.74 \\
\hline 50 & 41.168 & nonacosane & 47.70 \\
\hline 51 & 41.862 & trans-linalool oxide & 2.22 \\
\hline & & & \\
\hline
\end{tabular}

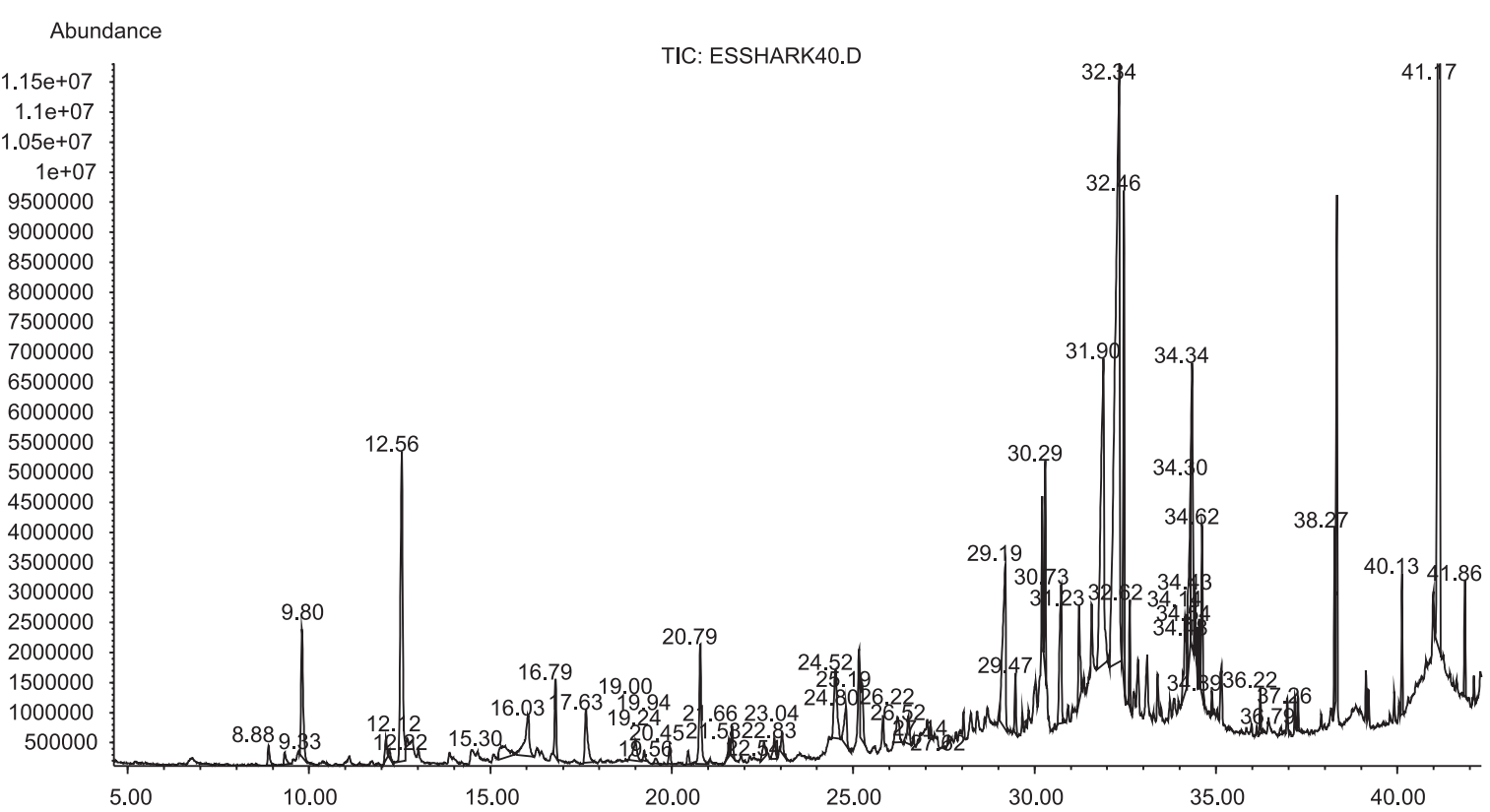


mass spectra). The retention indices of the components were calculated according to the results of control tests of substances with addition of the mixture of normal alkanes $\left(\mathrm{C}_{10}-\mathrm{C}_{18}\right)$. The quantitative content of each component $(\%)$ was determined by the method of internal normalization [4].

\section{Results and Discussion}

The yield of volatile substances was calculated from the sum of all areas on the chromatogram. The content of volatile substances is $0.025 \%$.

The results of the study of the chemical composition of the volatile fraction of cowberry leaves are presented in Table and Fig.

In cowberry leaves 50 volatile substances have been identified, identification of 1 substance has not been successful. Monoterpenes are presented by 14 substances, derivatives of linalool, geraniol, thymol and eugenol are prevalent. Caryophyllene oxide and farnesyl acetone $\mathrm{C}$ prevail among sesquiterpenes. Among organic and fatty acids the predominant substances are lauric, myristic, pentadecanoic, palmitoleic, palmitic, linoleic and linolenoic acids.

\section{CONCLUSIONS}

Using the method of gas chromatography the qualitative composition and quantitative content of volatile substances of cowberry leaves have been studied. Their content is $0.025 \%$.

In cowberry leaves 51 substances have been found, 50 of them have been identified. The predominant substances are monoterpenes, fatty acids and triterpenes presented by p-ment-1-en-8-ol, palmitic acid, ethyl palmitate, oleic acid, and squalene.

\section{REFERENCES}

1. Комісаренко М.А., Гейдеріх А.С., Ковальова А.М., Кошовий О.М. // Укр. журн. клін. та лабораторної медициини. - 2012.- №2. - C. 24-26.

2. Комісаренко М.А., Кошовий О.М., Зайцев Г.П., Ковальова А.М. // Зб. наук. працьь співробітників НМАПО ім. П.Л.Шупика. - 2015. - Вип. 24, кн. 5. - С. 127-131.

3. Комісаренко М.А., Кошовий О.М., Ковальова А.М., Сидора Н.В. // Зб. наук. праць співробітників НМАПО ім. П.Л.Шупика. - 2014. - Вип. 23, кн. 4. - С. 291-295.

4. Кошовий О.М., Комісаренко М.А., Ковальова А.М., Виноградов Б.А. // Фармац. журн. - 2012. -№4. - С. $101-104$.

5. Фролов В.М., Гарник Т.П., Гришина В.С. // Фітотерапія. - 2006. - №4. - С. 32-35.

6. Черногород Л.Б., Виноградов Б.А. // Pастит. ресурсы. - 2006. - T. 42, выл. 2. - C. 61-68.

\section{СКЛАД ЛЕТКИХ СПОЛУК ЛИСТЯ БРУСНИЦІ ЗВИЧАЙНОЇ \\ М.А.Комісаренко \\ Ключові слова: брусниця; листя; леткі речовини; газова хроматографрія; терпени}

Вивчення якісного складу та кількісного вмісту летких сполук листя брусниці звичайної проводили методом газової хроматографії. Ідентифрікацію речовин проводили на основі порівняння отриманих мас-спектрів з даними бібліотеки NIST05-WILEY (близько 500000 масспектрів). Індекси утримання компонентів розраховували за результатами контрольних аналізів сполук з додаванням суміші нормальних алканів $\left(C_{10}-C_{18}\right)$. У листі брусниці виявлено 51 речовину, 50 з яких ідентифріковано; домінуючими речовинами є сквален, пальмітинова кислота, етилпальмітат, олеїнова кислота. Встановлено, що вміст летких речовин складає 0,025\%. Монотерпени представлені 14 речовинами, домінуючими є похідні леналоолу, гераніолу, тимол та евгенол. Домінуючими речовинами серед сесквітерпенів є каріофріленоксид та фрарнезилу ацетон С. Переважаючими речовинами серед органічних та жирних кислот є лауринова, міристинова, пентадеканова, пальмітолеїнова, пальмітинова, лінолева та ліноленова кислоти.

\section{СОСТАВ ЛЕТУЧИХ СОЕДИНЕНИЙ ЛИСТЬЕВ БРУСНИКИ ОБЫКНОВЕННОЙ Н.А.Комиссаренко}

Ключевые слова: брусника; листья; летучие вещества; газовая хроматография

Изучение качественного состава и количественного содержания летучих соединений листьев брусники обыкновенной проводили методом газовой хроматографии. Идентификация веществ проводилась на основе сравнения полученных масс-спектров с данными библиотеки NIST05WILEY (около 500000 масс-спектров). Индексы удерживания компонентов рассчитывали по результатам контрольных анализов веществ с добавлением смеси нормальных алканов $\left(C_{10}-C_{18}\right)$. В листьях брусники обнаружено 51 вещество, 50 из которых идентифицированы; доминирующими веществами являются сквален, пальмитиновая кислота, этилпальмитат, олеиновая кислота. Установлено, что содержание летучих веществ составляет 0,025\%. Монотерпены представлены 14 веществами, доминирующими являются производные леналоола, гераниола, тимол и эвгенол. Доминирующими веществами среди сесквитерпенов являются кариофилленоксид и фрарнезила ащетон С. Преобладающими веществами среди органических и жирных кислот являются лауриновая, миристиновая, пентадекановая, пальмитолеиновая, пальмитиновая, линолевая и линоленовая кислоты. 